\title{
Pembuatan Model Fisis Letupan Gunung Lumpur Bledug Kuwu dan Pemodelan Numerik untuk Mengetahui Kecepatan Perambatan Gelombang Seismiknya
}

\author{
Ahmad Fauzi Pohan ${ }^{1}{ }^{*}$, Wiwit Suryanto ${ }^{2}$ dan Wahyudi $^{2}$
}

\begin{abstract}
Abstrak
Media fisis menggunakan akuarium berukuran $59 \times 59 \times 37,3 \mathrm{~cm}$ yang diisi material dari lumpur Bledug Kuwu. Sumber letusan dihasilkan dari tekanan kompresor yang dapat diatur kedalaman dan sudut sumbernya. Sinyal seismik direkam menggunakan geophone komponen vertikal sebanyak 3 buah dengan durasi perekaman selama 10 dan 5 detik. Data diambil dengan frekuensi sampel 2 dan $4 \mathrm{kHz}$ untuk masing-masing durasi perekaman. Pemodelan numerik dilakukan menggunakan metode finite-difference orde-4 teknik convolutional perfectly matched layer (CPML) untuk mencocokkan hasil dari pemodelan fisis. Konfigurasi sumber dan geophone dibuat sesuai dengan pemodelan fisisnya. Hasil model fisis diperoleh kecepatan perambatan gelombang- $P$ pada medium lumpur Bledug Kuwu adalah sebesar 48,74 m/s, dengan frekuensi dominan antara 20 sampai 25 $\mathrm{Hz}$. Hasil perbandingan antara seismogram model fisis dan seismogram model numerik diperoleh parameter kecepatan gelombang-S sebesar 28,14 m/s, densitas lumpur sebesar $1200 \mathrm{~kg} / \mathrm{m}^{3}$, dan conduit dari Bledug Kuwu membentuk sudut $30^{\circ}$ terhadap arah vertikal, dengan hasil korelasi antara model fisis dan numerik sebesar 0,9.
\end{abstract}

kata kunci: pemodelan fisis; pemodelan numerik; Bledug Kuwu; finite-difference; convolutional perfectly matched layer (CPML)

\begin{abstract}
The Physical model was a glass box with a dimension of $59 \times 59 \times 37,3 \mathrm{~cm}$ filled with Bledug Kuwu's mud. The eruption source is generated by a compressor pressure that can be controled both the depth and the angle of the source. The resulting seismic signals were recorded by using 3 vertical component geophones for 10 and 5 seconds durations at a frequency of 2 and $4 \mathrm{kHz}$ respectively. Numerical modeling was done by using a finite-difference method with a convolutional perfectly matched layer (CPML) to fit the results from the physical modeling. The source and geophone configuration was also made with the same configuration as the physical modeling. The physical modeling shows that the P-wave velocity of the Bledug Kuwu's medium is $48.7 \mathrm{~m} / \mathrm{s}$ with a dominant frequency of 20 to $25 \mathrm{~Hz}$. The comparison of seismogram from physical and numerical model gives S-wave velocity $28.1 \mathrm{~m} / \mathrm{s}$, mud density $1200 \mathrm{~kg} / \mathrm{m}^{3}$. It also shows the conduit of the Bledug Kuwu mud volcano system $30^{\circ}$ dipping. The correlation of the physical and numerical model is 0.9 .
\end{abstract}

keywords: physical model; numerical model; Bledug Kuwu; finite-difference; convolutional perfectly matched layer $(\mathrm{CPML})$

\section{Pendahuluan}

Fenomena gunung lumpur (mud volcano) merupakan salah satu bentuk manifestasi geologi yang tidak selalu ditandai dengan keluarnya material lempung

\footnotetext{
*Korespondensi: ahmad.binbe@gmail.com

1 Sekolah Tinggi Teknologi Industri Padang, JI. Prof. Dr. Hamka no.121, 25586, Padang, Indonesia

Informasi lengkap tentang penulis dapat dilihat pada akhir artikel

${ }^{\dagger}$ Equal contributor
}

(argillaceous) tetapi ada juga yang ditandai keluarnya gas pada permukaan bumi dan biasanya muncul pada daerah subduksi. Selain faktor tektonik tersebut, faktor batuan penyusun dari suatu daerah juga sangat mempengaruhi pembentukan gunung lumpur, dimana harus ada struktur cekungan elisional.

Beberapa karakteristik cekungan elisional, yaitu: pengendapan lapisan sedimen muda yang sangat cepat, adanya tekanan fluida yang sangat besar, 
lapisan sedimen yang tidak kompak dan tempat adanya minyak [1].

Pulau Jawa memenuhi faktor-faktor terbentuknya gunung lumpur, sehingga memunculkan sederetan gunung lumpur yang terbentuk pada permukaannya (Gambar 1). Beberapa hal yang menarik dari gunung lumpur yang muncul di Jawa Tengah hingga ke Jawa Timur diataranya Bledug Kuwu, yang memiliki aktivitas sangat kompleks dengan variasi erupsi dari ukuran besar hingga sangat kecil, yang terjadi pada beberapa saluran keluarnya material (conduit) [2].

Letupan gunung lumpur akan tetap terjadi jika memenuhi tiga komponen penting yaitu: sumber lumpur, jenis patahan, dan adanya kandungan gas didalam bumi. Patahan akan menjadi saluran yang dilalui oleh lumpur dan gas untuk keluar ke permukaan, bersamaan dengan pergerakan material pada saluran tersebut akan menghasilkan gelombang seismik yang merambat di medium.

Fenomena naiknya material lumpur dan gas melalui conduit kepermukaan bumi merupakan kajian menarik tersendiri dalam geofisika. Fenomena tersebut dapat dimodelkan baik secara analitik, numerik dan fisis (pada skala laboratorium).

Beberapa kajian seismik terkait gunung lumpur di Bledug Kuwu sudah banyak dilakukan diantaranya, oleh [3] dan [4]. Dari beberapa penelitian yang sudah dilakukan belum ada melakukan model fisis dari sistem erupsi lumpur yang keluar di permukaan. Sedangkan perambatan gelombang seismik menggunakan model numerik dengan metode finite-difference yang dilakukan [5] menunjukkan hasil yang stabil dalam perambatan di medium diskontuitas. Perkembangan metode ini menggunakan teknik convolutional perfectly matched layer (CPML) yang digunakan oleh [6]. Oleh karena itu pemodelan fisis suatu sistem erupsi lumpur menjadi hal yang menarik untuk dilakukan dan dibandingkan dengan model numeriknya.

\section{Metode Penelitian}

Adapun alat-alat yang digunakan dalam pemodelan fisis antara lain: Akuarium, Geophone, Styrofoam, Selang air, Penggaris, Kompresor, Busur derajat, Data logger, Kamera digital.

Perangkat lunak dan perangkat keras yang digunakan antara lain: Komputer, CorelDRAW X4, Microsoft Excel, Matlab R2009b, FORTRAN90.

Pengukuran dilakukan di Laboratorium Geofisika UGM, dengan menggunakan 3 buah geophone, sumber letupan berasal dari kompresor yang direkam menggunakan komputer/laptop dan setiap perekamannya berlangsung selama 10 detik untuk frekuensi sampel $2 \mathrm{kHz}$ dan 5 detik untuk frekuensi sampel $4 \mathrm{kHz}$. Adapun penggunaan frekuensi sampel $>1 \mathrm{kHz}$, di dasari atas jarak antara geophone yang sangat dekat (orde $\mathrm{cm}$ ). Dengan frekuensi sampel tersebut diharapkan, desain pemodelan fisis yang dibuat akan mendapatkan perbedaan masing-masing waktu tiba (arrival time) setiap geophone.

Penelitian ini melakukan pemodelan fisis dan numerik dengan konfigurasi sensor (geophone) dan sumber yang sama. Adapun desain pengukuran yang akan dilakukan seperti pada Gambar 2 dan Gambar 3 untuk pemodelan fisis dan Gambar 4 untuk pemodelan numerik.

Penempatan geophone 1 dekat dengan sumber bertujuan untuk merekam waktu awal letupan yang dilakukan (origin time). Dan peletakan geophone 2 dan 3 di permukaan lumpur bertujuan sebagai sensor rekaman seismik yang disebabkan oleh letupan lumpur. Susunan ketiga geophone ini dianggap sudah mewakili pengukuran yang sesungguhnya dilapangan.

Langkah-langkah pengolahan data pada penelitian ini adalah sebagai berikut:

1 Mengubah data yang terekam dalam format 'WDQ' menjadi format ' $t x t$ '.

2 Memotong sinyal yang mengandung event seismik.

3 Mengambil data gelombang pertama tiba dari event sinyal yang terekam di ketiga geophone.

4 Melakukan normalisasi terhadap sinyal yang dipilih.

5 Menghitung selisih/beda waktu tiba gelombang pada tiap-tiap geophone yang merambat pada medium (lag time) dengan menggunakan crosscorrelation[7].

Langkah 1-5 dilakukan secara berulang untuk semua data percobaan yang dilakukan (variasi kedalaman dan sudut dari sumber).

Sebaran gunung lumpur di Jawa Tengah dan Jawa Timur. Lingkaran biru menunjukkan fenomena letupan lumpur yang muncul di permukaan, sedangkan lingkaran hitam merah merupakan lokasi tempat penelitian [2]

6 Melakukan FFT untuk mendapatkan frekuensi dominan pada rekaman sinyal. Pengolahan data dimulai dengan melakukan langkah 1-2. Setelah langkah tersebut langsung melakukan FFT terhadap sinyal tersebut. Langkah ini dilakukan secara berulang untuk semua hasil rekaman (variasi kedalaman dan sudut dari sumber).

7 Melakukan filter pada rekaman sinyal disetiap geophone. Filter yang digunakan pada tahap ini menggunakan band pass filter untuk setiap hasil rekaman. Seismogram hasil filter tersebut akan dibandingkan dengan seismogram model numerik yang sudah difilter juga. 


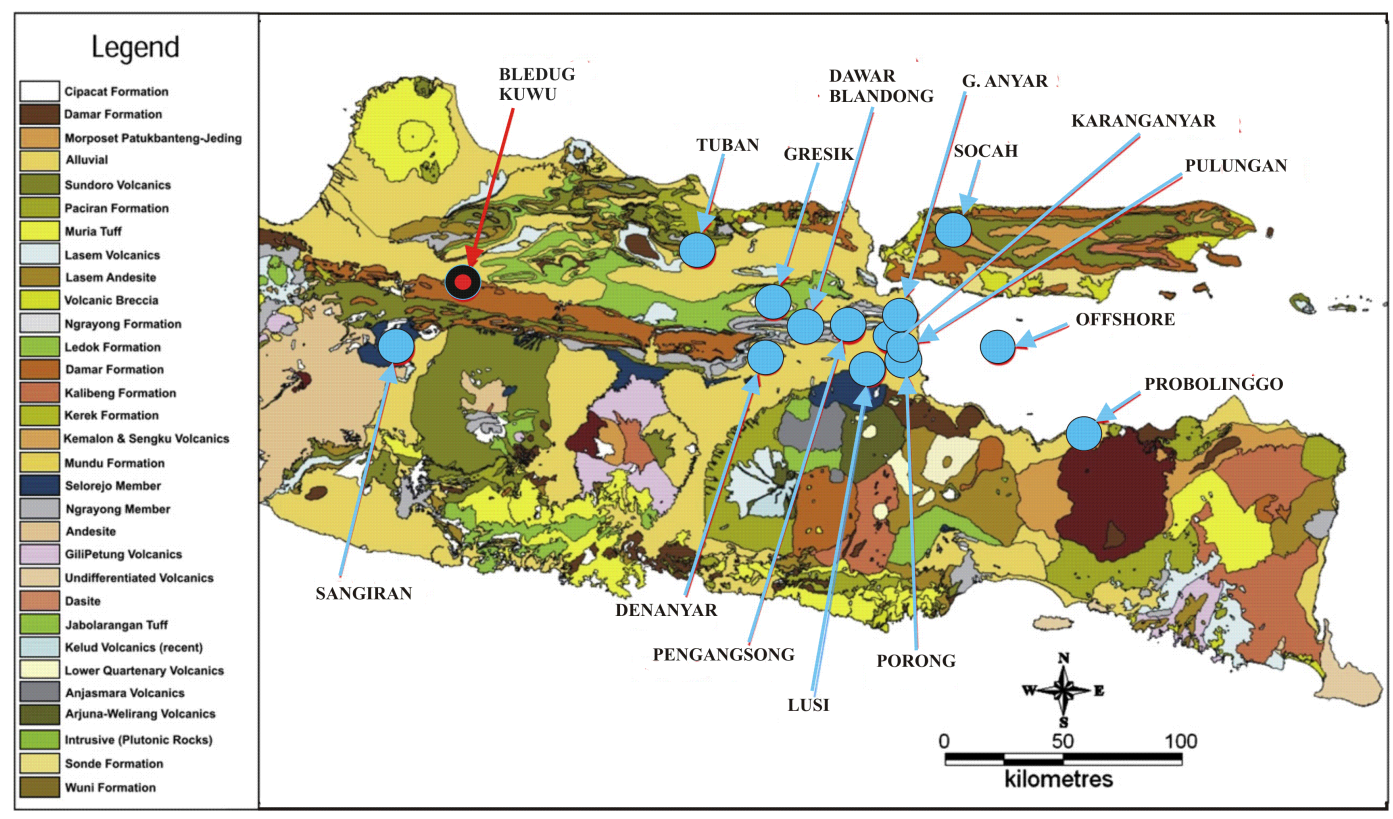

Gambar 1: Sebaran gunung lumpur di Jawa Tengah dan Jawa Timur. Lingkaran biru menunjukkan fenomena letupan lumpur yang muncul di permukaan, sedangkan lingkaran hitam merah merupakan lokasi tempat penelitian [2].

Dari awal sampai akhir penelitian yang dijelaskan sebelumnya secara sederhana diperlihatkan pada diagram alir penelitian pada Gambar 5.

\section{Hasil dan Pembahasan}

\subsection{Pemodelan Fisis}

Hasil dari perekaman sinyal kedua model fisis baik variasi kedalaman maupun variasi sudut sumber ditunjukkan pada ketiga seismogram yaitu: geophone 1 (merah), geophone 2 (hijau) dan geophone 3 (biru) (Gambar 6 dan 7).

Rekaman tersebut memperlihatkan perbedaan waktu tiba gelombang sangat kecil, tetapi terdapat perbedaan amplitudo pada setiap seismogram yang terekam antara geophone 1,2 dengan geophone 3 . Pembahasan ini hanya melakukan perbandingan antara geophone 2 dan 3 untuk besar amplitudonya, karena peletakan (posisi) dari geophone 2 dan 3 yang sama. Untuk geophone 3 besar amplitudonya sekitar $10 \%$ dari nilai geophone 2 . Hal ini disebabkan oleh geophone 2 merekam nilai maksimal stress pada medium yang disebabkan oleh letupan yang sudutnya $0^{\circ}$ (terhadap bidang vertikal) [6]. Selain itu berdasakan pengamatan langsung selama perekaman data, amplitudo besar diakibatkan oleh letupan yang terjadi tepat di atas geophone 2, sehingga membuat geophone terangkat lebih tinggi jika dibandingkan dengan geophone 3.
Seismogram pemodelan fisis dengan variasi sudut sumber diperoleh nilai amplitudo yang berbeda antara geophone 2 dan 3 (Gambar 7). Perbedaan besar amplitudo tersebut tidak sebesar yang terukur dengan variasi kedalaman. Hal ini menyatakan nilai stress yang diakibatkan letupan kompresor membentuk sudut $\left(30^{\circ}, 45^{\circ}\right.$ dan $60^{\circ}$ dari arah vertikal) berbeda dari nilai amplitudo pada sudut $0^{\circ}$ (variasi kedalaman). Rekaman sinyal tersebut diambil gelombang yang pertama tibanya dan dilakukan korelasi silang diperoleh perbedaan waktu tiba (lag time). Setelah itu dilakukan perhitungan untuk mendapatkan kecepatan gelombang-P dengan cara membagi jarak antara geophone dengan perbedaan waktu tibanya (Tabel 1, dan Tabel 2).

Nilai kecepatan rata-rata gelombang-P pada medium lumpur Bledug Kuwu diperoleh sebesar 48,7 $\mathrm{m} / \mathrm{s}$. Kecepatan ini lebih besar jika dibandingkan dengan kecepatan gelombang pada medium yang dihasilkan oleh [3] sebesar $(18 \pm 3) \mathrm{m} / \mathrm{s}$ tetapi lebih kecil jika dibandingkan dengan kecepatan perambatan gelombang yang dihasilkan [8] sebesar $1600 \mathrm{~m} / \mathrm{s}$.

Pada umumnya selain analisis sinyal dalam kawasan waktu juga dilakukan analisis dalam kawasan frekuensi. Analisis kawasan frekuensi diperoleh dari puncak-puncak spektrum suatu seismogram yang ditunjukkan pada Gambar 8. Spektrum tersebut menunjukkan banyaknya frekuensi yang terkandung didalam rekaman seismogram. Berdasarkan Gambar 


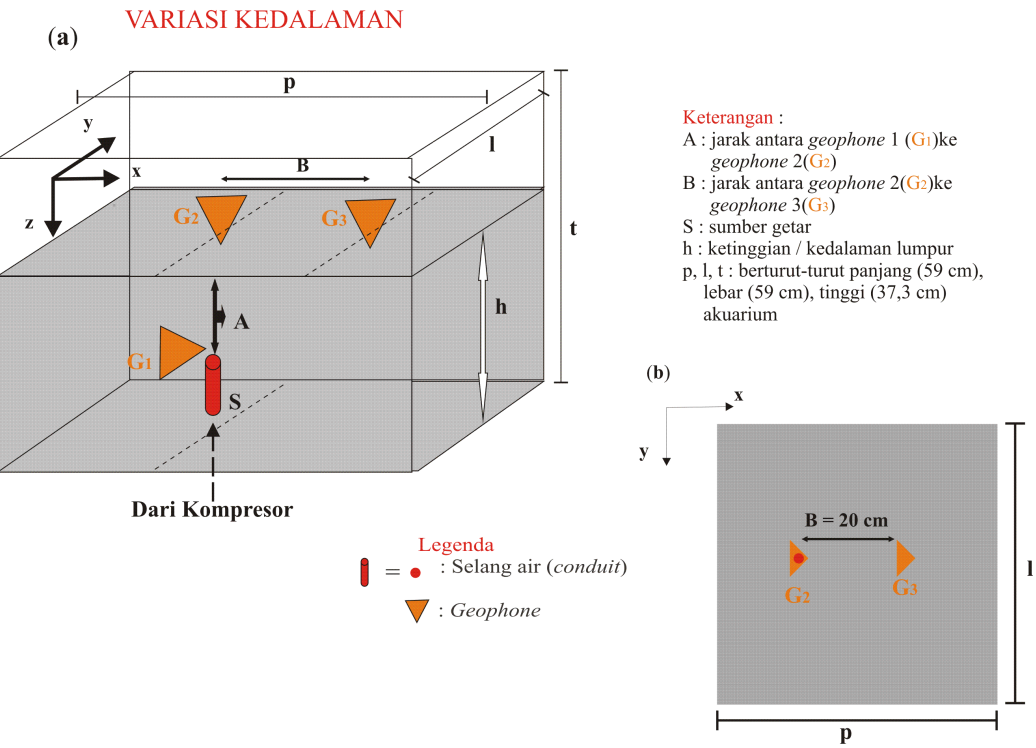

Gambar 2: (a) Kenampakan 3-D susunan geophone dan sumber getar dalam pengambilan data dengan memvariasikan kedalaman sumber (A), (b) kenampakan secara 2-D.

8 rekaman sinyal tersebut mempunyai frekuensi dominan pada 20 sampai $25 \mathrm{~Hz}$. Hal ini jelas terlihat pada geophone 3 yang memiliki satu puncak frekuensi. Frekuensi dominan yang dihasilkan pada penelitian ini berbeda dengan hasil penelitian oleh [3] dan [4] yang menghasilkan frekuensi rendah yaitu $1 \mathrm{~Hz}$. Hasil ini dapat diterima karena frekuensi bergantung pada kedalaman sumber, seperti model fisis yang dilakukan [9] dengan kedalaman sumber $12 \mathrm{~cm}$ menghasilkan frekuensi tinggi.

Berdasarkan nilai frekuensi dan kecepatan yang diperoleh menyatakan bahwa kecepatan gelombang yang merambat suatu medium sebagai fungsi frekuensi. Sifat gelombang ini disebut dispersi gelombang.

\subsection{Pemodelan Numerik}

Hasil rekaman seismogram untuk model variasi kedalaman yang ditunjukkan pada Gambar 9 terlihat bahwa gelombang yang pertama kali tiba diketiga stasiun hampir bersamaan, tetapi nilai dari amplitudonya berbeda. Amplitudo dari geophone 3 terlihat lebih kecil jika dibandingkan dengan amplitudo yang terekam pada geophone 2. Hal ini dapat terjadi karena posisi geophone 3 yang relatif jauh jika dibandingkan posisi geophone 2. Posisi/jarak yang jauh dari sumber letupan mempengaruhi nilai energi gelombang yang merambat pada suatu medium. Selain itu posisi geophone 3 membentuk sudut terhadap arah keluarnya letupan, yang menengakibatkan nilai stress terhadap bidang vertikal besarnya berkurang jika dibandingkan dengan posisi geophone 2 .

Rekaman seismogram untuk variasi sudut sumber ditunjukkan pada Gambar 10. Gelombang pertama tiba pada setiap geophone memiliki perbedaan waktu tiba yang sangat kecil, tetapi nilai dari amplitudonya berbeda. Hal ini berbeda dengan hasil yang diberikan oleh variasi kedalaman, dengan nilai amplitudo pada geophone 2 dan 3 memiliki nilai yang relatif sama. Amplitudo tersebut menjelaskan bahwa nilai stress akibat dari letupan yang membentuk sudut di dalam medium yang terekam di geophone 2 dan 3 relatif sama. Secara teori nilai amplitudo berubah merupakan hal yang benar berdasarkan nilai maksimal stress pada medium yang disebabkan oleh letupan yang sudutnya $0^{\circ}$ (terhadap bidang vertikal) [6].

\subsection{Perbandingan Model Fisis dan Numerik}

Perbadingan hasil seismogram model fisis dengan seismogram model numerik dilakukan dengan dua cara yaitu, cara subjektif dan objektif. Hasil perbandingan antara model fisis dan numerik ini menunjukkan bahwa model dengan variasi sudut sumber lebih mirip dari pada model dengan variasi kedalaman (Gambar 11). Ini dilihat dari kemiripan seismogram saat dilakukan overlay. Secara khusus ditunjukkan pada Gambar 5.23 (model variasi sudut sebesar $30^{\circ}$ ) dengan nilai koefisien korelasi masing-masing pada geophone 1, 2 dan 3 yaitu 0,9105, 0,8905 dan 0,9295.

Hasil ini sesuai dengan penelitian dari [4] yang mengestimasikan bahwa conduit lumpur Bledug Kuwu 
VARIASI SUDUT ( $\theta$ ) DARI SUMBER GETAR

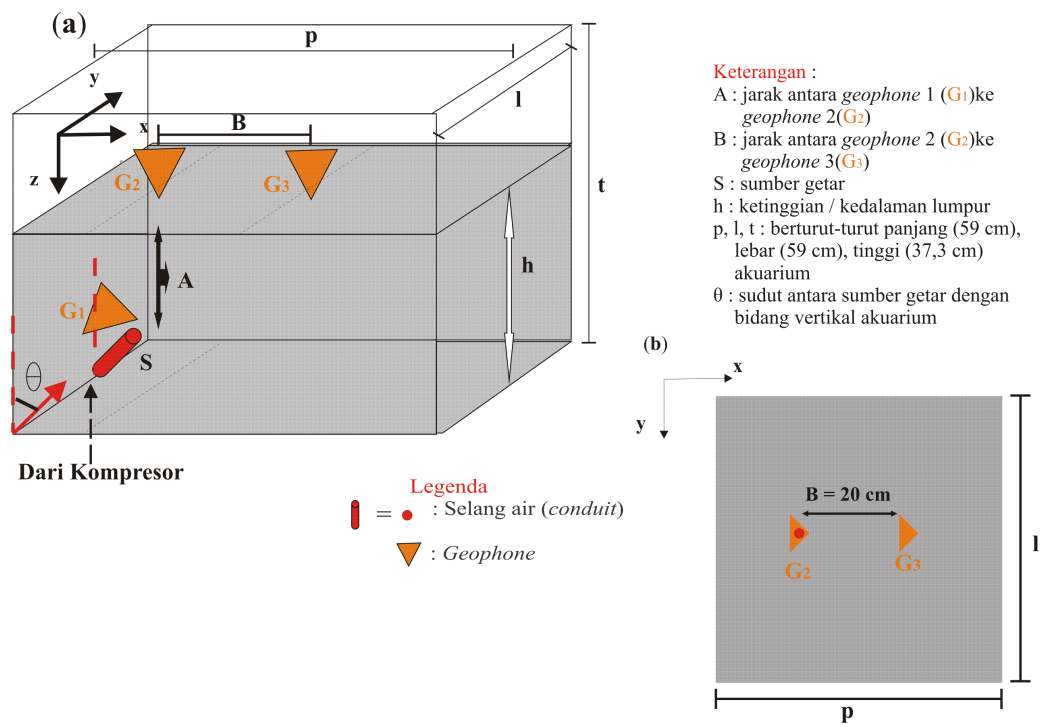

Gambar 3: (a) Kenampakan 3-D susunan geophone dan sumber getar dalam pengambilan data dengan memvariasikan sudut dari sumber getar $(\theta)$, (b) kenampakan secara 2-D.
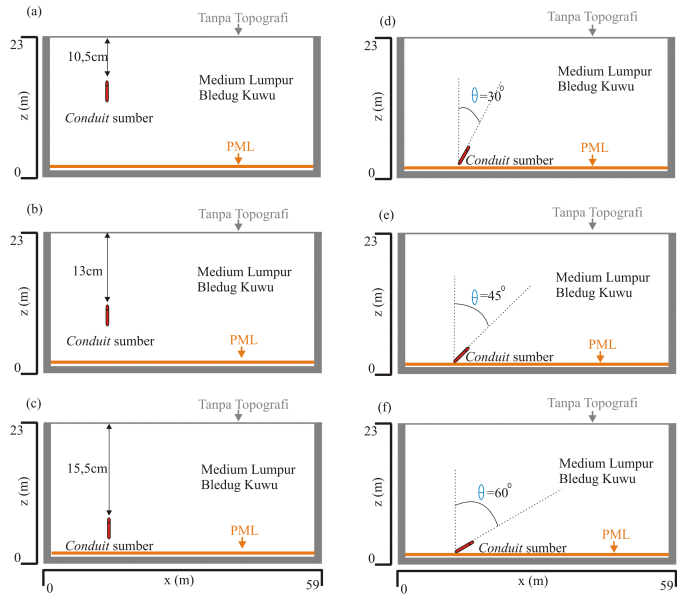

Gambar 4 Model homogen 2D yang akan dimodelkan dengan memvariasikan kedalaman dari conduit sumbernya, (a) (b) (c) kedalaman $10,5 \mathrm{~cm}, 13 \mathrm{~cm}, 15,5 \mathrm{~cm}$. (d) (e) (f) sudut $30^{\circ}$, $45^{\circ}, 60^{\circ}$.

miring (membentuk sudut). Maka dapat disimpulkan bahwa parameter-parameter dari medium lumpur Bledug Kuwu yaitu : kecepatan gelombang- $\mathrm{P}=48,7$ $\mathrm{m} / \mathrm{s}$, kecepatan gelombang-S $=28,1 \mathrm{~m} / \mathrm{s}$, densitas lumpur $1200 \mathrm{~kg} / \mathrm{m}^{3}$, dan conduit dari sistem lumpur Bledug Kuwu membentuk sudut $30^{\circ}$. Adapun model dari kenampakan gunung lumpur Bledug Kuwu berdasarkan penelitian ini ditunjukkan pada Gambar 12.

\section{Kesimpulan}

Beberapa hal yang dapat disimpulkan dari pembahasan yang dilakukan sebagai berikut:

1 Kecepatan rata-rata perambatan gelombang-P pada medium lumpur Bledug Kuwu sebesar 48,7 $\mathrm{m} / \mathrm{s}$.

2 Pemodelan fisis dilakukan dengan variasi kedalaman dan sudut sumber, yang durasi rekaman selama 5 dan 10 detik untuk frekuensi sampel masing-masing 2 dan $4 \mathrm{kHz}$. Pemotongan rekaman sinyal diambil sepanjang 1,5 detik (yang terjadi event saja). Pemodelan ini menghasilkan nilai frekuensi dominan berada pada frekuensi 20 sampai $25 \mathrm{~Hz}$. Frekuensi tersebut sekaligus menjadi frekuensi filter (band pass filter) yang dilakukan pada seismogram model fisis.

Tabel 1 Kecepatan gelombang- $\mathrm{P}$ dengan variasi kedalaman sumber

\begin{tabular}{|cllllll|}
\hline Kedalaman (cm) dan & \multicolumn{7}{c|}{ Kecepatan Gelombang-P (m/s) } & Rata- \\
Frekuensi Sampel & 1 & 2 & 3 & 4 & 5 & rata \\
\hline 10,5 dan $(2000 \mathrm{~Hz})$ & 52,5 & 35 & 35 & 42 & 35 & 40 \\
13 dan $(2000 \mathrm{~Hz})$ & 52 & 43,3 & 43,3 & 52 & 52 & 48,5 \\
15,5 dan $(2000 \mathrm{~Hz})$ & 44,3 & 62 & 51,6 & 51,6 & 62 & 54 \\
10,5 dan $(4000 \mathrm{~Hz})$ & 38,2 & 30 & 46,6 & 35 & 24,7 & 35 \\
13 dan $(4000 \mathrm{~Hz})$ & 37,1 & 47,2 & 57,7 & 40 & 32,4 & 43 \\
15,5 dan $(4000 \mathrm{~Hz})$ & 56,3 & 47,6 & 62 & 56,3 & 47,6 & 54 \\
\hline
\end{tabular}

3 Konfigurasi pada pemodelan numerik dibuat sama dengan model fisisnya. Setiap variasi kedalaman maupun sudut sumber telah diperoleh seismogram perekaman dengan durasi 1,5 detik dan telah dibahas. Nilai amplitudo yang terekam 


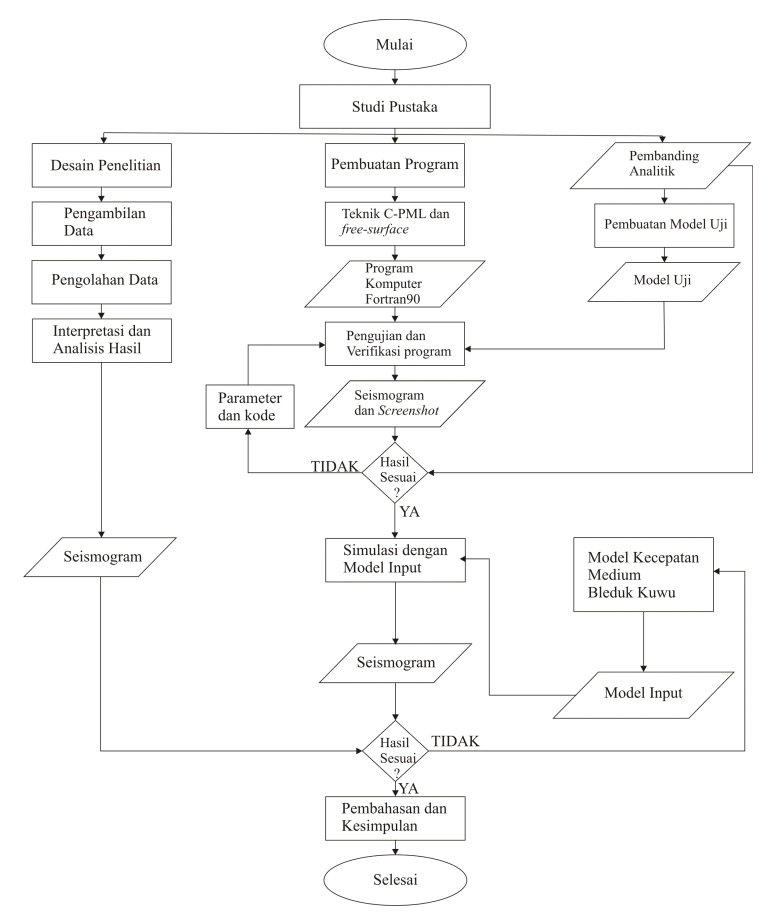

Gambar 5 Diagram alir penelitian.

Tabel 2 Kecepatan gelombang- $P$ dengan variasi sudut sumber

\begin{tabular}{|clllllll|}
\hline Sudut (derajat) dan & \multicolumn{9}{c|}{ Kecepatan Gelombang-P (m/s) } & Rata- \\
Frekuensi Sampel & 1 & 2 & 3 & 4 & 5 & rata \\
\hline $30^{\circ}$ dan $(2000 \mathrm{~Hz})$ & 41,2 & 30 & 55 & 27,5 & 55 & 41,8 \\
$45^{\circ}$ dan $(2000 \mathrm{~Hz})$ & 50,5 & 39,3 & 44,2 & 35,4 & 44,2 & 42,8 \\
$60^{\circ}$ dan $(2000 \mathrm{~Hz})$ & 64,2 & 77 & 77 & 55 & 96,2 & 74 \\
$30^{\circ}$ dan $(4000 \mathrm{~Hz})$ & 44 & 47,1 & 38,8 & 55 & 50,8 & 47 \\
$45^{\circ}$ dan $(4000 \mathrm{~Hz})$ & 44,2 & 59 & 54,5 & 47,2 & 47,2 & 40 \\
$60^{\circ}$ dan $(4000 \mathrm{~Hz})$ & 70 & 70 & 55 & 70 & 59,2 & 64,8 \\
\hline
\end{tabular}

sangat dipengaruhi oleh variasi kedalaman dan sudut sumbernya. Seismogram perekaman tersebut juga difilter pada frekuensi yang sama dengan model fisis untuk mendapatkan seismogram model numerik tanpa gangguan.

4 Perbandingan model fisis dan model numerik untuk setiap variasinya dilakukan dengan melakukan overlay dan melakukan crosscorrelation antara kedua seismogram tersebut. Hasil perbandingan kedua model memperoleh nilai kemiripan (koefisien korelasi) yang tinggi pada variasi sudut sumber, dengan nilai untuk geophone $1=0,9105$, geophone $2=$ 0,8905 , geophone $3=0,9295$. Sehingga parameter medium lumpur Bledug Kuwu yang dihasilkan dari perbandingan kedua pemodelan tersebut yaitu: kecepatan gelombang-S sebesar 28,1 $\mathrm{m} / \mathrm{s}$. densitas lumpur sebesar $1200 \mathrm{~kg} / \mathrm{m}^{3}$, dan conduit dari sistem lumpur membentuk sudut $30^{\circ}$ terhadap arah vertikal.
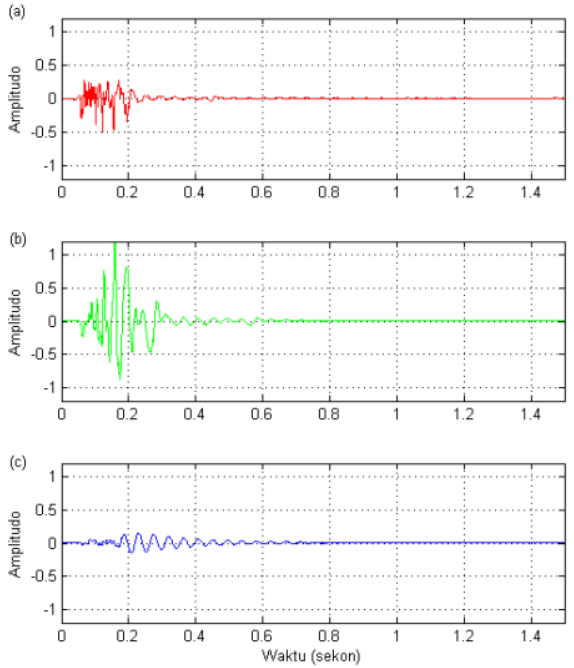

Gambar 6 Seismogram perekaman model fisis dengan variasi kedalaman sumber. (a) geophone 1, (b) geophone 2 dan (c) geophone 3 .

\section{Informasi penulis}

${ }^{1}$ Sekolah Tinggi Teknologi Industri Padang, Jl. Prof. Dr. Hamka no.121, 25586, Padang, Indonesia. ${ }^{2}$ Department of Physics, Universitas Gadjah Mada, Sekip Utara PO BOX BLS 21, 55281, Yogyakarta, Indonesia.

\section{Pustaka}

1. Satyana, A.H., Asnidar: Mud diapirs and volcanoes in depressions of java to madura: Origins, natures, and implications to petrolium system. In: 32 Annual Convention and Exhibition, pp. 139-158 (2008). Indonesian Petroleum Asosiation

2. Istadi, B.P., Pramono, G.H., Sumintadireja, P., Alam, S.: Modeling study of growth and potensial geohazard for lusi mud volcano: East java, indonesia. Marine and Petroleum Geology (26) (2009)

3. Sugiantoro: Studi Gelombang Seismik Mikro Pada Medium Dua Fase di Daerah Kuwu Kabupaten Grobogan Jawa Tengah

4. Sugianto, N.: Analisis Polarisasi Gelombang Seismik Erupsi Bledug Kuwu Menggunakan Seismometer Tiga Komponen

5. Virieux, J.: P-sv wave propagation in heterogeneos media: Velociy-stress finite-difference method. Geophysics 51(4) (1986)

6. Komatitsch, D., Martin, R.: An unsplit convolutional perfectly matched layer improved at grazing incidence for the seismic wave equation. Geophysics 72(5) (2007)

7. Brigham, E.O.: The Fast Fourier Transform (FFT) and Its Applications. Prentice Hall, New Jersey, USA (1988)

8. Putranti, A.B.: Pemodelan Kecepatan Medium Bawah Permukaan Bledug Kuwu Dengan Metode Spatial Autocorrelation (SPAC)

9. Rust, A.C., Balmforth, N.J., Mandre, S.: The feasibility of generating low-frequency volcano seismicity by flow through a deformable channel, fluid motion in volcanic conduit a source of seismic and acoustic signals.

Geophysics 307(9) (2008) 

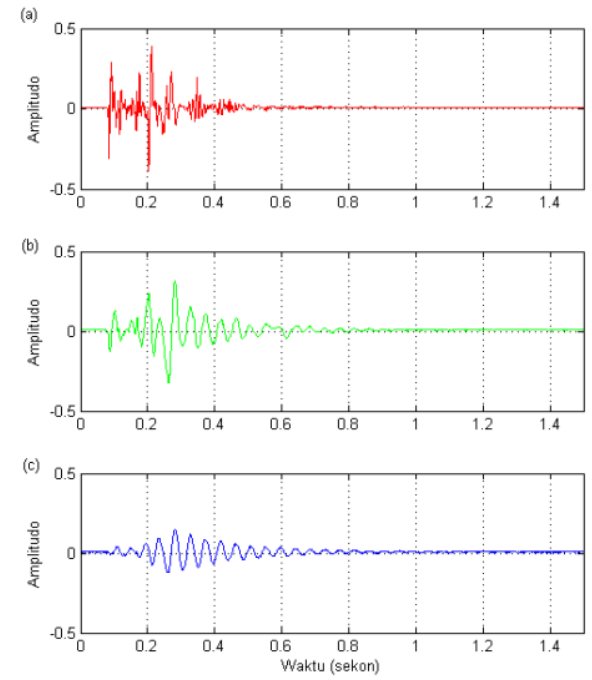

Gambar 7 Seismogram perekaman model fisis dengan variasi sudut sumber. (a) geophone 1, (b) geophone 2 dan (c) geophone 3 .
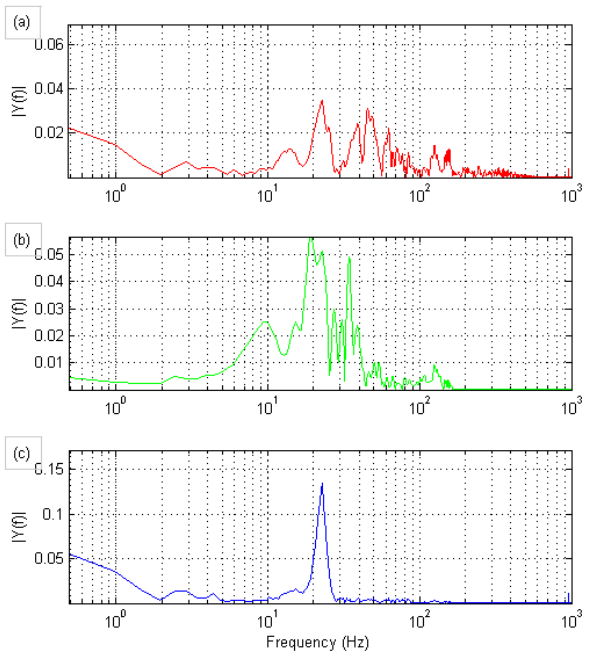

Gambar 8 FFT dari seismogram perekaman model fisis. (a) geophone 1, (b) geophone 2 dan (c) geophone 3.
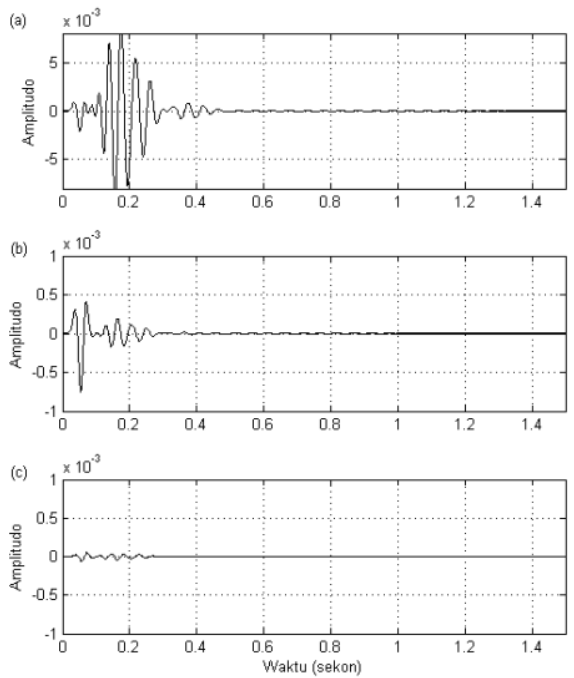

Gambar 9 Seismogram rekaman model numerik dengan variasi kedalaman sumber. (a) geophone 1, (b) geophone 2 dan (c) geophone 3.
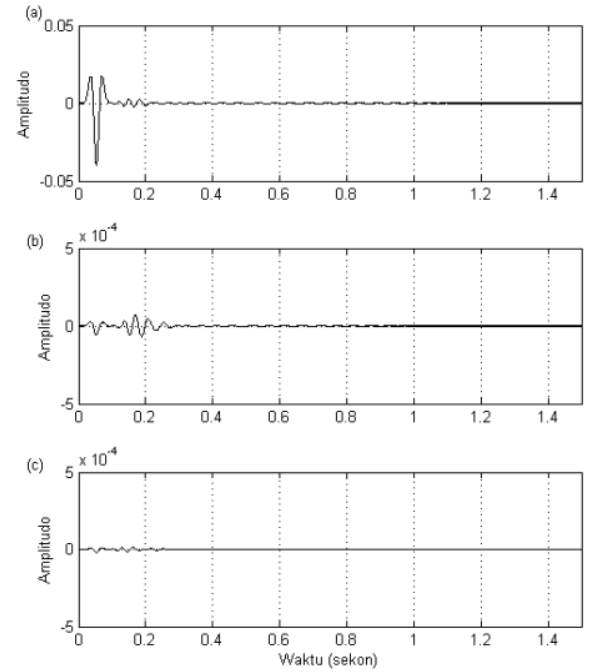

Gambar 10 Seismogram rekaman model numerik dengan variasi sudut sumber. (a) geophone 1, (b) geophone 2 dan (c) geophone 3 . 

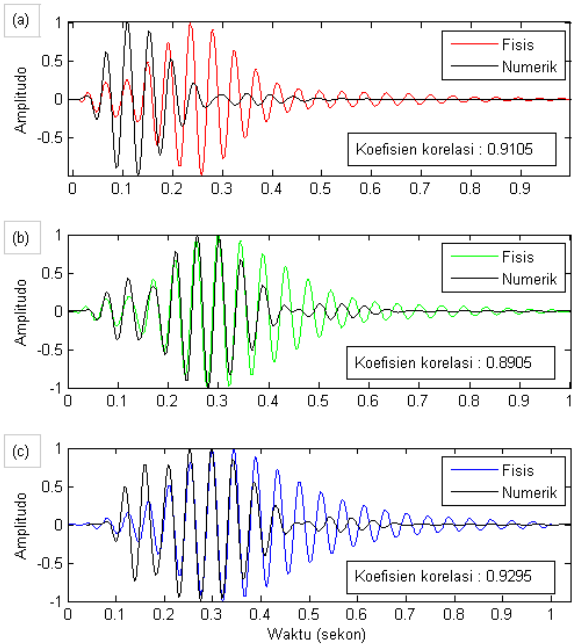

Gambar 11 Perbandingan seismogram model fisis dan numerik pada sudut sumber $30^{\circ}$. (a) geophone 1 , (b) geophone 2 dan (c) geophone 3.

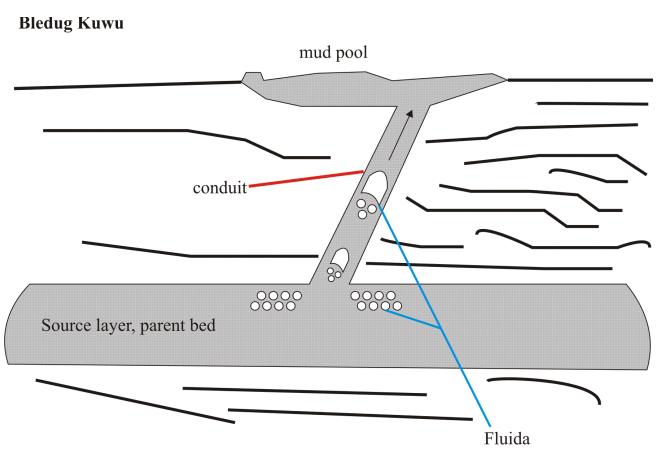

Gambar 12 Model gunung lumpur Bledug Kuwu. 